\title{
The black church as the womb of black liberation theology?: Why the Uniting Reformed Church in Southern Africa (URCSA) is not a genuine black church?
}

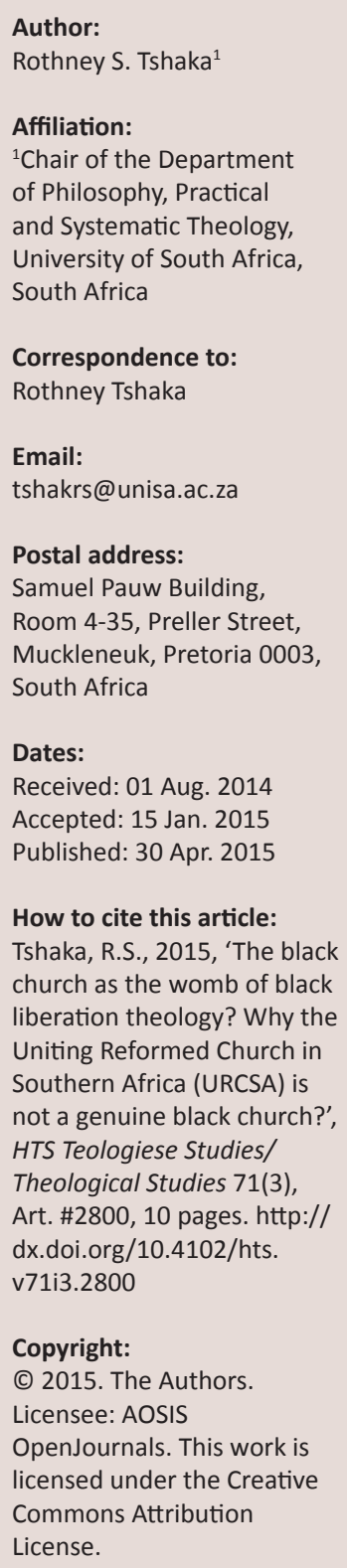

This article sets forth a controversial thesis which suggests that the Uniting Reformed Church in Southern Africa, although considered a black church, is in fact not a black church in the sense in which a radical black church is traditionally understood. A black church, it is argued, is perceived to be one that is a self-determined church which supports initiatives of ameliorating the depressive situations in which black people find themselves. References are made to black theology as a critical theology which was never accepted in the black church due to the dependency syndrome which was brought about by the white benevolence of the Dutch Reformed Church. This, it is argued, had become innate in the Uniting Reformed Church in Southern Africa which still considers itself as a so-called daughter church of the white Dutch Reformed Church.

\section{Introduction}

The suggestion that the Uniting Reformed Church in Southern Africa (URCSA) is not a black church appears mischievous at first. I say this because it is clear that this church, which is comprised of a large section from the Dutch Reformed Church in Africa as well as the Dutch Reformed Mission Church, is made up of those people who were classified as non-white and therefore as black people by the then apartheid regime. The classification of black and mixed-race still remain as credible descriptions of groups of people in present-day South Africa.

However, the assertion that the URCSA is in fact not a black church is also true, especially when one considers the relationship of a particular church in patronising a particular theology. It is the latter aspect of what has been explained here that this article wishes to probe. It will also be shown that the example of a black theology of liberation is taken from a context where churches patronised a particular theology because they felt it was a theology with which they could relate. I am thinking here especially of churches that paid homage to the likes of Nat Turner, the Baptist preacher in the United States of America (USA) around the 1830s, and Harriet Tubman (Hopkins 2002:30). This article will demonstrate the role played by black churches in ensuring that they possess a theology that could help them relate to their circumstances and still insist on being Christian.

The South-African context, it will be argued, was very different when compared to the USA context, and that situation sadly, still exists even today. I refer to the USA context because it is a fact that Black theology of liberation was transplanted to South Africa from the USA. Motlhabi (2007:1) argues movingly that '... Black Theology in South Africa followed closely on the heels of American Black Theology and is closely related to it'. Whilst, in the case of the former, we had churches that could, from a very early period, identify fully with black theology, in South Africa, we had individual students and ministers as well as some institutions that identified with black theology although conditionally. From the earliest time in South Africa, we had talk of black theology in the Black Theology Project (BTP) of the University Christian Movement and the South African Students Organisation (SASO), which subscribed to the philosophy of Black Consciousness, the Black Community Programmes (BCP), Interdenominational African Ministers Association of South Africa (IDAMASA) and the African Independent Churches Association (AICA) (Motlhabi 2007:1-2).

The Belydende Kring (BK) could also be credited for at least exposing some ministers of the then DRCA to some black theology (Kritzinger 1984:5-12). In the case of the DRCA and the DRMC which later became the URCSA, it was virtually impossible to even consider fully identifying with black theology since this theology has always wrongly been perceived as being political. Additionally, the fact that the URCSA is seen as a daughter church to the Dutch Reformed Church 
suggests that she is dependent on said church. This is seen also in the theological education curricula of the URCSA. The centres for the theological formation of the URCSA are located at Stellenbosch University, Free State University as well as at the Northern Seminary which has affiliations with both the University of Pretoria and the University of South Africa. Curricula at all these centres remain Eurocentric with African and black theologies falling into a category called Third-World theologies. I am of the view that the bias for Eurocentric theology exists because the South African theological ground was never conducive to bring forth a true black theology of liberation. Doing black theology of liberation in the black church depends on a few important factors to which Jeremiah A. Wright Jr refers. He writes:

The doing of black theology in the black church depends on the geographical location of the pastor and the people. It depends on the psychological location of the minister and his or her members. It depends on the cultural location of the clergy and the congregation, and it depends on the theological location of the leadership of the church and the membership of the church. (Wright 2004:13)

Wright (2004:13ff.) continues to spell out what he means by the four factors for doing black theology in the black church. I shall not belabour those factors which are otherwise significant for understanding the praxis of black theology of liberation in a black church. Ours is to engage with the information in application to the URCSA context.

The URCSA came into existence in 1994. This church is comprised of a merger between the former Dutch Reformed Mission Church (DRMC) and a huge portion of the Dutch Reformed Church in Africa (DRCA). The unification process occurred after the DRMC had produced the BelharConfession, which essentially bemoaned the theological justification of apartheid by the white Dutch Reformed Church (DRC). It is true that the Belhar Confession was drafted by the Dutch Reformed Mission Church in 1982 and was approved in 1984 as part of the DRMC's confessional basis. As mentioned, the Belhar Confession dismissed apartheid as a sin and a heresy. It cannot, however, be said that it was only the DRMC that was questioning the theological legitimacy given to apartheid by the DRC at the time.

Ministers who were affiliated with the BK were already strongly engaged in the struggle against apartheid, but it must be remembered that the presence of white missionaries in the DRCA made it virtually impossible for these ministers to be too vocal on the issue of apartheid (Kritzinger 1984:5-12). In fact, it was because members of the DRCA themselves in their various synods had already repudiated the theological justification of apartheid that it became easy for them to talk of unity which finally happened in 1994.

That the URCSA was founded in 1994 is important to note. This is a watershed year in the history of South Africa.
Nelson Mandela became president in that year, and it was generally taken as the beginning of a new chapter for the miracle child of the world. That also meant that a particular language was to be sought, a language that avoided racial talk and focused instead on nation building. In a sense, the search was on for a language that was politically neutral. Maluleke (1997) captures this clearly when he says the following:

Unable to mobilise its resources and speak boldly to the new situation, it seems that even the 'liberal progressive branch' of South African theology and South African ecumenism is, at least for now, only able to engage in the building of theological castles in the air. Therefore we have seen an alarming increase in the manufacture of 'new' theologies, most of which fail to respond to the situation of the 'victims of gross violations of human rights' - if I may borrow that rather narrow perspective. These new theologies either tend to sing praises to Nelson Mandela and his government or engage 'the new world order' in highly middle class terms by seeking to 'strengthen or deepen' such vogue notions as universal human rights, nation-building, political economy, civil society, democracy, etc. (pp. 13-14)

This ultimately meant that a compromise needed to be made. Just like the negotiated settlement called forth the new South Africa, so theology needed to take a leaf from that book and follow, especially when some of the former protagonists of black theology of liberation were assimilated into the new regime. ${ }^{1}$

Just like its history of continued settlements with former oppressors and new governors, academic theology in South Africa seems to be inclined to follow this trend in presentday South Africa. Black theology as a critical theology had to be replaced with contextual theology during the period of political vacuum in South Africa because white people who were involved in the struggle felt left out by the definition of black theology. It is also possible that the reason why black theology at that time did not engage the issue of African culture and beliefs was because African culture was also seen by the black learned elite as uncivilised.

Motlhabi (2007:22) refers to Biko who lamented the point that the histories of black people were consistently being ignored. So it seems that, in a democratic dispensation, black theological language is changed into some 'neutral theology' because neutral language best embodies the spirit of a rainbow nation brought about by the negotiated settlement, called the new South Africa.

1.One can think of individuals who were especially featuring very prominently during the TRC process. Amongst them may be counted the likes of Desmond Tutu, chair of the TRC process. Amongst them may be counted the likes of Desmond Tutu, chair of the TRC, vice-chairperson Alex Boraine (former Methodist minister), Khoza Mgojo, (liberation theologian and former president of the SACC), Charles Villa-Vicencio (prolific theologian), Bongani Finca (church leader and prominent ecumenist), Tom Manthata (former employee of the Justice and Reconciliation Division in the SACC) Rev. Xundu and Prof. Piet Meiring (former moderator of the Eastern Transvaal Synod of the Dutch Reformed Church (DRC)). Other prominent theologians joined academic institutions during that period. One can here think of Simon Maimela Takatso Mofokeng and Itumeleng Mosala. Others like Barney Pitjana headed the South African Human rights commission. 
It is, therefore, not by chance that many prefer neutral language in opposition to language that insists on the particularity of some reflections. It will be argued that the present context is no different from the context in which black theology of liberation was established in South Africa. For this very reason alone, it will be argued, black theology as liberation theology is a relevant discourse today.

In present-day South Africa, it has become common to hear bold sentiments concerning the irrelevance of black theology of liberation. ${ }^{2}$ In this article, I shall explore where such hubris originates and why public theology, just like contextual theology not so long ago, is punted as the most preferred ilk of theology in academic discourses today in South Africa. It is hoped that a clearer picture will be painted of why black theology of liberation was never able to percolate the masses at a time when it was popular amongst some black seminarians and black ministers.

Some reasons for this failure and the continued misconception of this theological enterprise as elitist would be mentioned. Since black theology of liberation cannot be thought of without, at the same time, making reference to the church, the subject of the church will be explored. This research will focus specifically on the URCSA and generally on Black mainline churches in South Africa. The issue of curriculum will also be engaged as this remains a pivotal aspect in the conversation regarding the relevance of black theology of liberation today.

This article, it is hoped, will demonstrate why a call for the continued relevance of black theology of liberation is necessary more than 20 years into a democratic dispensation in South Africa. It is believed that this call is also relevant given the indications that Christianity is gravitating towards the global south. Having argued why this theological enterprise remains significant in a colour-blind South African context, this article will move to engage the future of this theological enterprise which must begin critically to engage issues of economic hegemony in current South Africa.

By now, I trust that my assertion that the URCSA is not a black church has been elucidated. A black church is one which insists in taking the lived experiences of black people seriously in theological reflection. I believe that this assertion is informed especially by the view that black theology of liberation was a guerrilla enterprise which was never welcomed in both church and in academia. This assertion is also informed by the factors spelled out by Wright in this article. I shall explain why it was impossible for this ilk of theology to be welcomed both in the church and in academia. I shall then look at the evolution of black theology

2.It has become a standard question every time I am giving a talk on black theology of liberation: Is this theology still relevant today in a democratic South Africa? I always dismiss this question by saying that I am not aware of any funeral that took place to bury black theology. Therefore as far as I am concerned and in the circles that frequent, black theology is in fact more needed today in democratic South Africa than ever before. I am of the view that this question, 'Is Black theology still relevan today?', is simply informed by arrogance, arrogance that is aimed at dismissing Black realities as unreal and fictitious. of liberation in South Africa and, lastly, at the changed and changing face of theology in South Africa today.

\section{The black church as the womb of black theology of liberation}

In the context of the USA, black theology of liberation was and remains intrinsically linked to the black church and subsequently to the black community (Lincoln, cited in Billingsley 1999:xx). This is emphasised by Eric C. Lincoln in his introduction to Billinsley's (1999) book titled, Mighty like a river: The black church and social reform. Lincoln argues:

Black religion takes its origins not from established religion in America, but from the black experience in America, which was and is a very singular illustration of the complexities of the human predicament, and of the spiritual resources available to the black church's mission to overcome. (p. xx)

He continues to assert the following:

... from its inception, the black church set out to do for its peculiar constituency of black slaves and freed men[sic] what no one else was willing to do for them, or to have them to do for themselves. (Lincoln, cited in Billingsley 1999:xx)

For Lincoln, the black church came about after the realisations of black people that:
... though they were finally 'in church', it was demonstrably not 'their' church, a communication that spoke pointedly and consistently through the sermons, prayers, the spiritual suppression, and the absence of fellowship. In the white churches, Africans were offered a God who had cursed them and ordained their travail and debasement in perpetuity. (cited in Billingsley 1999:xxi)

Lincoln (cited in Billingsley 1999:xx) is quick to point out that the earliest incubators of the black churches were South Carolina and Georgia, and these churches were established by the ex-slave Richard Allen in Philadelphia in 1815.

Lincoln in is adamant in insisting:

In the early black church the first emphasis was on getting to know God more intimately, and getting used to the idea that black people were not cursed of God, nor condemned by God to be 'hewers of wood and drawers of water' for the white people who called themselves 'masters'. (Billingsley 1999:xx)

Contrary to the white church in which they never felt welcome, it was in the black church that these black people experienced church as the giver of security and God's comfort. It is for this reason, argues Lincoln, that:

\footnotetext{
... the black response - the prayer and the preaching, the singing, the moaning, the shouting (or as W.E.B du Bois put it, 'the frenzy') - kept the human spirit alive and the presence of God an assured consolation. (cited in Billingsley 1999:xxii)
}

James Cone (1992) echoes these very sentiments in his book titled, The spirituals and the blues. 
Remembering where he first made contact with this 'frenzy', Cone (1992) asserts:

At the Macedonian African Methodist Episcopal Church, the melody, rhythm, and style were black; the mood was black; and the people were black. Everything they did was a valiant attempt to define and structure the meaning of blackness - so that their children and their children's children would be a little 'freer' than they were. (p. 2)

These gentlemen believed that identity was vital in challenging the hegemonies that kept black people in their place. The black church that Lincoln, Billingsley, Cone and others are trying to present to us is the very one which, in insisting on a black identity, also knew the significance of providing for its constituency as Lincoln intimated earlier on. It is for this reason that he (Lincoln, cited in Billingsley 1999:xxiii) specifically points out that, '[ $t$ ]he black church sponsored schools, savings societies, insurance companies, banks ...' It was through being seen as visible in black communities that the black church became to be considered the most formidable bastion of Black solidarity (Lincoln, cited in Billingsley 1999:xxiv).

Why was it important for this church to insist on its identity as being black and to take great strides in ensuring that its offspring are a little freer that its forebears? For us to get a clearer picture of this subject, it is necessary to briefly consider how the dislocation of the black self happened and why these people in fact became a vulnerable people.

Hopkins and Antonio put this succinctly with reference to the (black) vulnerable in society. This article therefore takes its cue from them. According to Hopkins and Antonio (2012:4ff.), the vulnerable and the marginal in society refer chiefly to those black peoples of African descend whose largest displacement and forced migration happened around the year $1441 \mathrm{CE}$ when they were given as a gift to Prince Henry of the Christian country of Portugal.

This is for us the initial context if we are to deal with this subject in a proper perspective. The modern context of globalisation and capitalism must also be understood in view of this initial displacement. It is the argument of this article that the current socio-economic, cultural and political challenges are a direct result of the action first engineered in the 15th century. Thus the 'nervous condition' ${ }^{3}$ which has been created by the initial greed and exploitation on the African continent cannot and must not be seen as a singular event unrelated to the original large displacement and exploitation of African people.

If the black church is the womb for black theology, it follows naturally that this church is in fact the mother of black theology. If the black church is indeed the mother, there are

\footnotetext{
3.The notion 'nervous condition' is taken from Jean-Paul Sartre in the preface to Frantz Fanon's book titled. The wretched of the earth (2007). It became popular when it became the title of a novel by the Zimbabwean novelist Tsitsi Dangarembga, when it became the title of a novel by the Zimbabwean novelist Tsitsi Dangarembga,
describing the odds a girl child had to go through to attain an education in a patriarchal and traditional context (Dangarembga 1988).
}

also other aspects to consider. One of these is the fact that, although black theology took as its point of departure the material conditions in which black folk found themselves, in some instances, it also lost the zeal for freedom which had propelled it into existence. This point is made here to underscore the point that the black church was not a homogenous construction. The de-radicalisation of the black church in the USA, which started during the early 20th century when Bishop Henry Turner's influence declined, rendered the black church a different church to the one it used to be in its inception (Wilmore 1984:135ff.).

It is because of this de-radicalisation, Cone (1993) would say:

\begin{abstract}
... that the black churches of today, with a very few exceptions, are not involved in liberation but primarily concerned about how much money they raise for a new church building or the preacher's anniversary. (p. 271)
\end{abstract}

It goes without saying that this de-radicalisation of the black church happened post-1994 when key black theologians in South Africa accepted offers to lead academic institutions and or to be part of government. It would seem that the durability of apartheid as a system was so intact that most of these black theologians did not think it would be defeated in their lifetime, hence the lack of investing in this project for future generations. Another aspect has to do with the church and whether it had the potential to patronise this project. This refers to the factors well-articulated by Wright (2004) earlier in this article.

\section{Why no cultural womb for black theology of liberation in South Africa?}

A brief introduction into the study of black theology immediately reveals the black church as taking centre stage (Cone 1984). For the likes of Cone especially, theology must be fore-grounded in the context of the very people to whom this good news is being preached (Cone 1984). This is significant for, as the likes of Lincoln and Mamiya (1990:2f.) would surmise, the black church acts as the bastion of the black community.

Seen this way, it would therefore seem that the absence of such a church, which is meant to be the bedrock of a community and to shape the identity of a particular community, would inevitably lead to the non-percolation of black theology of liberation into black communities. Without a doubt, the black church of which the likes of Cone, Lincoln and others spoke contributed to the empowerment of the struggling black communities in the USA. These churches were concerned not only with the spiritual but particularly with the very material conditions of their adherents as indicated.

As far as the question of a black church as the womb of the black community in South Africa is concerned, it is my view that such a church does not exist, specifically within the mainline black church tradition and more specifically 
in the URCSA. This is so because, since the arrival of black theology to the shores of South Africa, it has only enjoyed the status of a guerrilla enterprise. ${ }^{4}$ By this, I suggest that black theology of liberation as an alternative hermeneutics was never welcomed into the South African academia and church. We have already seen this when I explained in the introduction that there was no church within the mainline church tradition which openly identified with black theology. It is for this reason that you will not find any traces of black pride and black culture in mainline black churches in South Africa and especially within the URCSA.

In a context where the apartheid geography has virtually remained the same, one is bound to find a black church that insists in mimicking its Dutch Reformed heritage. This is evidenced by the liturgies, church orders, et cetera that were simply taken from the previous era. In a context where there is so much talk about the need for Africanisation, there has been no a single attempt at indicating that the URCSA wants to insist on her Africanness. This is to be expected if one takes into account the dependant syndrome that has virtually come to dictate the relationship of the URCSA to the DRC. This is evidenced in rural communities where so-called daughter churches are still dependant on the so-called mother church for the sustenance of the local black church.

Reformed white theology continues to be the most dominant theological trajectory 20 years into a democratic dispensation. It is this very theology which continues to set the standard of 'proper theology' in the South-African church and society. Even though there is no unity between the black URCSA and the white DRC, it is white theology that is prescribed even in seminaries that belong to the URCSA. This is the state of affairs, and this has always been the state of affairs. This has to do with what Wright (2004:15) refers to as the theological location of the clergy and the congregants. The black URCSA does not have its own theology and never had its own theology. This also speaks to the fact that the curricula offered is copied from the DRC's curricula. Black theology which takes issues of black experience seriously in theological discourse is still considered a marginal and Third-World type of theology even for theological education in Africa. This is evidenced by the fact that black theology falls within the category of 'Third-World' theologies in many prominent faculties of theology across South Africa. Third World here is informed by Pletsch's understanding of the role of such categorisations. Pletsch has observed the division of the world into 'first, second and third world'. To explain this briefly, Pletsch (1981) argues that:

... the distinctions among First, Second and Third World allowed Western social scientists to develop a disciplinary division of

4.The notion of 'guerrilla' is borrowed, referring to little wars or to those who participate in small numbers against the established order. When used in conjunction with black theology, the word refers to the fact that black theology, since its inception in South Africa, has always been seen as not academic enough, especially when it used Marxist analytical tools in theological reflection. For detailed exposition of this, see especially Mosala (1989). Therefore, for black theology, th condition of black suffering became a significant starting point for theological reflection. For the debate on the epistemology of black theology, see the PhD dissertation of V. Vellem (2007). labor that nonetheless permitted them to assume a privileged place in the order of things. (p. 574)

The absence of a 'black church' proper to act as the womb for black theology of liberation was the sole reason why black theology of liberation could not percolate black communities. There were reasons for that. Chiefly, apartheid had as one of its objectives to make black people what they were not. It essentially believed it was possible to extract a so-called human being from his or her abominable black skin.

Boesak (1998:416) is absolutely correct when insisting that '... when our Khoi ancestors were confronted with Christianity for the first time, it was the Reformed expression of it that they experienced'. What was not said in that statement was that becoming a member of this new faith literally meant giving up the language with which you grew up and taking on a foreign name. Not speaking some gibberish language, as the languages of the Khoi and Blacks were understood at that time, meant that you were more civilised than the rest.

In applying Miroslaf Volf's exclusion and embrace, Kritzinger was able to illustrate this patronising attitude expressively. Pointing to Volf, Kritzinger (2010):

... pointed out that exclusion can take four forms: (a) elimination ('the only good ... is a dead ...') (b) assimilation ('they' must become 'like us') (c) domination ('they' must know 'their place') (d) apathy and indifference (they leave me cold). (p. 211)

Kritzinger (2010) also continues to point out how Volf argues that exclusion and violence can be exercised with language. Clearly my views about a search for inclusion and authentication as suggested by Kritzinger have changed dramatically. I remain of the view that to be self-sufficient first and not to be dictated to by our so-called white mother church is the only solution to creating a black church that is self-determined.

There are a number of great pointers made by Kritzinger in the mentioned article with regard to ministerial formation. However, I do not think that the bigger issue receives enough attention, namely the question of whose theology we are talking about and for whom this theology is meant. Other than that, I believe that the article by Kritzinger is relevant in as far as it documents a patronising attitude that is still at large today. The theological curricula which dominated the ministerial formation of the URCSA are in my view still too Western. I believe that these curricula are intentionally designed and adhered to so that 'we can meet out white brothers and sisters at some point'. The very issues that are perceived as marginal by some and falling into the category of 'third-world theologies' are the issues that we intentionally place high on the agenda to underscore what is important and relevant to us. Perhaps without saying much, it does appear to me that Black people have internalised the perception that there is nothing in Africa from which we can learn.

Black people, who have grown up in these so-called daughter churches, were only too happy and proud to carry the label 
of daughter churches because of their affiliation to the white mainline churches. This difference justified the low view that they would have of Black people who were affiliated to the African Initiated Churches (AIC) for instance. The latter were perceived to be too backward and uneducated and were never to be taken seriously. Mafeje (1975) puts this into clear perspective when he argues the following:

It is evident that Langa is pervaded by a Christian middleclass ideology which denigrates paganism and which places a premium on Christian education as a civilising influence and a source of respectability. (p. 170)

Another reason for this low view, which was essentially engendered by academic theology in South Africa, is that the AIC are mostly associated with mekhukhu. Mekhukhu generally denote squalor and landlessness, Vellem would argue. There can be no doubt that most of the AICs congregate in mekhukhu (shelters), and the majority of their adherents also dwell in these mekhukhu. ${ }^{5}$ These mekhukhu, says Vellem (2010:4), '... represents the psychosis and paralysis of social life that is a reality, a concrete experience of millions of South Africans who attend every Sunday in mekhukhu' (plural of mokhukhu). Whilst this is a concrete reality for many, (and it must be emphasised that the majority of these people are in fact Africans) this squalid situation is by no means justified by Vellem. He argues movingly that '... a mokhukhu is a residual symbol of a repugnant socio-political malady that links black theology to the present challenges of prophetic witness' (Vellem 2010:5). Daughter churches of the mainline churches fell into the trap of thinking of themselves as better than the so-called AIC which were in essence not seen as churches but sects. This is what Mafeje (1975:169) refers to when he says that, ' $\ldots$ as people are described as "educated" or "uneducated" in Langa, so are churches divided into "genuine" (icawe yokwenyani, a true or real church) and "fake" (oozenzele, self-made)'. This perception of oppressed people thinking that they are better-off than the rest because they imitate the mannerisms of the oppressor is furthermore captured movingly by Carter Woodson (2008) in his epic work, the Mis-education of the Negro.

Most mainline church traditions had so-called daughter churches. Therefore, it is improper to confine this criticism to the URCSA. Mainline churches had theological schools where their black members could be educated to the level of minister of word and sacrament. Yet these very ministers were never taken to be good enough to be seen as being the same as their white counterparts. All those other churches that were not affiliated with mainline churches were considered sects not to be taken serious by any serious theologian. This mentality is still alive and well. It was these white mainline churches which continued to dictate curricula to the so- called (black) daughter churches. Although the curriculum was slightly modified in the black seminaries,

5.The prominent South African anthropologist Archie Mafeje makes this point poignantly clear when he refers to the schism that has been brought about between those who are affiliated with the mainline churches and those who are affiliated with the so-called AIC. I refer to this later in this article. it remained white and therefore removed from the context and realities of these seminarians. One must read this in a context sketched by Joseph Conrad (2007) and western epistemologies propagated by the likes of Hegel and others (Hegel 1956:12-13). Consequently Africa as a continent must continue to be grateful to the West because of its benevolence in spite of the affliction it has caused and continues to cause to Africa.

Being aware of the perceptions that was and in some instances still are, with regard to AICs - that those affiliated with this school are apolitical - we need to recognise that some within this school were not as cowardly. Siqibo Dwane (2004:75) maintains that '... on 1 November 1892, in Pretoria, the Reverend Mangena Mokone and a group of African colleagues withdrew their membership of the Methodist Church and subsequently founded the Ethiopian Church'. He continues to point out that '... the Reverend Mokone was nice enough to indicate his reasons for leaving the Methodist church in a letter with a list of grievances which centred on racism' (Dwane 2004:75). One must also bear in mind that Zionist movement in South Africa is not a homogeneous group. It ranges from radical to apolitical groupings, all claiming the same Zionist heritage.

What about black theology of liberation then? Given this situation, it is significant to ask whether this theological enterprise could thrive, given the circumstances. The short answer is not at all. The dependency syndrome which came as a result of white benevolence made it impossible for black theology to percolate black daughter churches. There were major impediments that laid deep in white benevolence which were projected as Christianity. Firstly, when surveying the literature of the dominant theology of the time, and specifically literature from the white DRC, one sees how the subject of white benevolence is interwoven in the transactions with the non-Europeans. This can be seen, for instance, in a piece of literature titled 'Die N.G. Kerk in the O.V.S en die Naturelle Vraagstuk' (1929). From this document, one gets a sense of policy that spells out the relationship of the DRC with black people, at least within the Free State. Under the heading, Die Heiden, die erfdeel van Christus, the meeting argues: 'eis van my en Ek sal $\mathrm{u}$ gee die Heidene, $\mathrm{u}$ erfdeel, en die einde van die aarde, $\mathrm{u}$ besitting' [require from $\mathrm{Me}$, and I shall give you the heathen, your inheritance, and the ends of the earth, your possession].

Whilst there has certainly been a great improvement in relationships between white and black people, the inculcated views about the other have not been dealt with adequately. We see this in the fallacious assumption that South Africa is one united country and the miracle child of the world. South Africa's international standing as the miracle child of the world continues to force this community to evade issues of race and the continued negative impact it has on the country. It is therefore not by chance that, throughout the evolution of critical theologies in this country, a neutral 
language was and is still often sought to speak to and feed the perception that we had overcome our terrible racial existence.

Examples of these are legion and varied, namely contextual theology at a time when there was a political vacuum in the country, and of late, we hear much about public theology another careful and evasive title that seem to be embraced by anyone who is uncomfortable with race talk. ${ }^{6}$ It is important that we are careful about this inclination. In his USA context, Wright (2004) argues as follows:

\begin{abstract}
... a large number of African American clergy and congregations who do not see the themselves as African American but perceive themselves rather as multicultural or (as Cornel West and Mike Dyson argue) as hybrids have lost their cultural centre. They have forgotten where they came from and have forgotten their story. (p. 15)
\end{abstract}

\section{The history and impact of black theology of liberation in South Africa}

We have already in passing made reference to black theology of liberation in South Africa in this article. Black theology of liberation emerged in South Africa during the late 1960s. As a project, it was inspired by the Civil-Rights Movement in the USA, the prophetic voice of Martin Luther King Jr, Malcolm X's critique of white racism in the USA as well as the pioneering work of James Hal Cone. It was transported from the shores of the United States of America to South Africa as an intellectual project which was made possible by the then University Christian Movement (UCM) in 1971 (Motlhabi 2007:7ff.). All this occurred under the directorship of Basil Moore and was first spearheaded in South Africa by Sabelo Ntwasa. Clearly impressed by the audacity of a theological reflection that takes its location seriously, this theological enterprise appealed to many young ministers and students of theology. Within the context of the URCSA, I have already alluded to the $B K$ and especially the Christian Institute which had taken the Black Consciousness Movement seriously.?

Black theology of liberation was expressed under the banner of the black consciousness movement of South Africa, which owes its being to students such as Steve Biko, Barney Pityana, Harry Nengwenkulu and others who were galvanised by the then political situation into organising themselves into a vanguard for the black peoples' total emancipation from the political pangs into which they were plunged by white racism in South Africa (Motlhabi 2007:7). Although black theology propagated itself chiefly by means of seminars and ministers' caucuses, it produced some significant publications and continued into the Kairos period.

\footnotetext{
6.A number of publications, which carried the notion of public theology, have surfaced, for instance Storrar (2008). The issue of where this type of theological surfaced, for instance Storrar (2008). The issue of where this type of theological reflection places black
Maluleke (e.g. 2011).
}

7.For a detailed overview of the Christian Institute, see Walshe (1983).
A number of the first-generation black theologians endeavoured to develop black theology in relationship to their confessional traditions. Amongst these theologians can be counted the likes of Manas Buthelezi, Desmond Tutu and Allan Boesak. This project was carried on by theologians such as Buti Tlhagale, Takatso Mofokeng, Bonganjalo Goba and Itumeleng Mosala, to mention but a few (Tshaka 2010:232).

It is in my view fair to describe black theology of liberation in South Africa as a guerrilla enterprise as I have done earlier on in this article. I call it a guerrilla enterprise whilst the likes of Dwight Hopkins (2002:161) call it a theology outside of the castle of the mainstream. Either way, these names speak of a theology that remains aware of its lack of popularity within the castle of the mainstream. Those that engaged this theology had to find alternate platforms where these ideas could be shared and propagated, hence the black seminars and black ministers' caucuses already mentioned above.

The economic disparities between black and white people made it even more difficult for black churches to assert their independence and to openly embrace this theological hermeneutics. Some AICs, which came into existence primarily because they were not content with a theology that refused to take seriously the black experience in theological reflection, were considered too radical and were dismissed as mere sects, not to be taken seriously by any 'proper' theological reflection (Dwane 2004:80).

It is very interesting to note that this became a dominant perception in the reflections of the very black protagonists of black theology. Black churches of the mainline tradition were and still are very much dependent on the so-called white mother churches, and so, in an attempt to be different from the rest, there was never an intentional move to align themselves with the indigenous churches as they wrestled to make culture and African world views important elements in their reflections. This is the major contention between African theology as espoused by John Mbiti and others and black theology as adapted to the South Africa situation during the apartheid era. Mbiti (1993:379ff.) has made his criticism vocal from the very start.

For black theology of liberation, the struggle was waged more on a political level. The perception was, we assume, that once political power is gained, the economy would simply conform to the dictates of politics. Thus not much has been done in terms of economic and cultural democracy (Cruse 1967). That especially the element of culture was ignored in the struggle for the assertion of black people as human beings became one of the greatest criticisms from our Westand East-African counterparts. Motlhabi (2007:8) refers to an irate response from John Mbiti (1993) who wanted to have nothing to do with black theology since, according to him (Mbiti), it did not take seriously the issue of African culture and world views. 
The fact that black theology of liberation was a guerrilla enterprise posed significant challenges to its attempts at percolating the very black communities it intended to empower as mentioned earlier. Firstly, since black theology of liberation was chastised as 'improper theology', the apologetics of black theology of liberation developed an obsession with theological method instead of dealing with the concrete particular realities of black people in South Africa. There has been no theological enterprise in South Africa that obsessed with theological method as black theology of liberation did, hence my statement that the early protagonists of black theology of liberation developed it along their confessional affiliations (Tshaka 2010:232). A clear example of this can be found in Boesak's (1984) Black and reformed and others.

Secondly, the question of economic dependence played a major role in the inability of this theology to percolate the black communities, and instead, it resulted in an elitist enterprise in some instances. The question of economic dependency had shown how, in the case of South Africa, a very well-meaning and imperative initiative such as black theology of liberation can evaporate into an elitist project that is used as a springboard to personal well-being.

When taking into account the different role players in the emergence of black theology of liberation in South Africa, one cannot but wonder whether the suggestions today that this theology is irrelevant, were not to be expected. To begin with, black theology of liberation was an initiative that, to some degree, enjoyed the patronage of some white liberals. Because of their involvement in black theology of liberation, some of them felt that they equally had the right to determine the direction of this theology for the future. The likes of Steve Biko remained very critical of the involvement of our white friends in the affairs of black people. His statement, 'black man you are on your own', (Biko 1987) gives credence to his view that white people who are sincere about structural racism can only help the black course when they engage white racism and privilege in their respective circles.

It is unfortunate that the black consciousness element in black theology dwindled and ultimately disappeared totally from black theological discourses in post-apartheid South Africa. This is evidenced by the move away from black theology of liberation to contextual theology in the late 1980s and early 1990s. The 1999 multi-event held in Cape Town is, in my view, one event organised by our white liberal friends in conjunction with some black protagonists of black theology to chart a new direction for critical theology. The summary analysis of the proceedings was titled, 'Constructing a language of religion in public life' (Cochrane, Martin \& Walters 1999). The mentioned preparatory meeting proposed a language that is friendly to all in the new South Africa. There is in my view nothing wrong with such an approach unless the particularity of the black reality is compromised.

\section{The changed and changing face of Christianity}

It is within the church that theology gets its relevance. In a time when statistics are showing that Christianity is flourishing in the Global South, it is perhaps significant to ponder the question of the significance of a black church in South Africa today. Mainline church traditions, to which I belong, were never willing to accept the existence of a black church. What I mean by this is that the creation of so-called daughter churches for the so-called non-white population never afforded these churches an opportunity for selfdetermination. Whilst they were allowed to congregate in their own spaces, they were always made dependent on the benevolence of the white mother church.

Patronage was increased if there were indications of the daughter churches exfoliating their cultural skins and perceptions. This is evidenced in the church orders which were hell-bent on insisting that African culture and worldviews were to be discouraged by all means necessary. The Church order of the URCSA seems particular ignorant of the question of Africanity since it speaks evasively about marriage. This is the only instance when something related to Africa is mentioned (cf. Church order and stipulations of the Uniting reformed Church in Southern Africa 2011:77, especially stipulation 61).

In a way, these mainline churches, although all black, discounted the black experience as an important element in theological reflection and in a sense embraced the secondclass citizenship tag that was given to them by the white hegemonies and that was supported by these white mother churches. It was for this very reason that black theology of liberation found it extremely difficult to percolate these churches. The notion of a 'black church' derives its meaning from the context of slavery in the USA as profusely explained earlier in this article. Black slave communities gathered together, usually on Sunday mornings when good white folk were gathering in their churches to hear how good God was and how the same God had predestined the serf position of black folk (Lincoln \& Mamiya 1990:5). Whilst white folk were worshiping this God, black slaves did the same, wanting to accept their position of subjugation in a strange land. It is my understanding therefore that the notion 'black church' cannot be understood apart from a spirituality which had sustained itself throughout the most difficult period in the lives of black people in the USA.

These are churches which formed themselves along the exodus experiences. These initial slave churches are the custodians to the work songs which later became the Negro spirituals and had always insisted that God had not made a mistake in creating black folks. Research on the spirituality of these communities clearly presents the notion of spirituality as an ambivalent notion. In fact, spirituality proper cannot be understood unless one recognises its inherent ambivalence (Cone 1992:42). 
There is of cause another dimension to this phenomenon, and that is its elasticity and significance for those on the margins of society. It was none other than James Cone who helped me to understand the endurance of the black soul in a context of harsh oppression. In his book, The spirituals and the blues, Cone (1992:53ff.) reminds us how black slaves could to some extent understand their oppressed condition by identifying particularly with the oppressed people in the Bible.

Of this ambivalence of spirituality, Cone (1992:20) writes: "To create the future in the "extreme situation" of American slavery was very difficult for black slaves. It meant accepting the burden and the risk of the not yet'. He continues:

Actually when they encountered the divine presence and promise, as revealed in the event of Jesus' death and resurrection, they knew that there was only one possibility for authentic human existence. And that was to live in freedom for the future. (Cone 1992:21)

Logic therefore becomes nonsensical in such a situation.

In the South African context, we realise that a theology that seem to have percolated black communities is the very theology that intentionally does not link structural injustices, for instance, with the spirituality of its adherents. Therefore, in a way, there is great similarity between the black USA and black South African contexts. One therefore has to use the notion (black church) in the South African context in the same manner that black people use the notion in the USA context simply because mainline churches, although separate along racial lines, have always dictated a theology for their black daughter churches.

\section{The future of black theology of liberation: Conclusion}

The first democratic election of South Africa in 1994 is perceived as the best miracle to have happened to a country fraught with contradictions. Some prefer to see it as a clean slate and intentionally prefer to discount a history of the exploitation of black people in this country. I subscribe to a school of thought which is of the view that capitalism and democracy are contradictory ideologies.

Sampie Terreblanche (2005:16) argues that '... while democracy emphasizes joint interests, equality and common loyalties, capitalism is based on self-seeking inequality and conflicting individual and group interests'. What is more important, notes Terreblanche (2005), is that:

The legal system that protects both democracy and capitalism is based on the principle of equality before the law, but maintains inequality in the distribution of property rights and opportunities in the capitalist system. (p. 16)

For him (Terreblanche 2005:17), the logic of capitalism given the unequal freedom and unequal rights upon which it is based - goes against the grain of the logic of democracy. It is important for me to point this out simply because democracy is invariably thrown into the debate. We are to forget about a capitalist and exploitative history which is largely responsible for the current problems and struggle and defend democracy with our lives if necessary.

Our obsession to want to be relevant and to illustrate that black theology of liberation is indeed genuine theology has done tremendous harm to us. We had become alienated from our contexts, and in some instances, we had been assimilated into the very structures of oppression that black theology of liberation was struggling against. However, this was to be expected for as Hopkins (2002) had warned:

'Entering the 'castle' of the mainstream and being faithful to a gospel of liberation can present damaging possibilities. Those who take seriously African American though (or in our case, those who take seriously African thought) as central to constructing a theology risk losing all the privileges gained in the castle when they persist in using the phrase 'black theology' and, more specifically, 'black theology of liberation of the poor'. The reason is that the more opportunities they have, the more pressure arises from structural authority to blunt an accent on liberation of social relationships on earth. From the perspective of the status quo it could be much more better [sic] to domesticate, tame and legitimize black religious studies. (p. 163)

Hopkins has been prophetic, for the domestication of black theology of liberation has certainly started, and this is evidenced by all sorts of notions that are used to replace black in liberation theology. The challenge today is to acknowledge how the castle operates and yet to struggle to make the lived experiences of black people central in theological discourse in South Africa. ${ }^{8}$ There is no future for black theology of liberation in South Africa unless this theological enterprise can create its own space and dictate its own terms for its continued relevance and survival.

Creating such space and dictating its terms for survival suggests that black theology of liberation will have to continuously ask the critical and uncomfortable questions that affects those still on the receiving end of history. Today more than ever, black theology of liberation must give answers to the questions of those on the wrong side who want to make sense of what their citizenship means in present-day South Africa if they are not able to gain access to the basic necessities for surviving. Above all, it needs to find ways of helping them reconcile God with their present situation of need.

We acknowledge that nobody can do for black theology of liberation what it must do for itself. We realise that there is a serious contest taking place where black theology of liberation is contesting for a space to engage critically with the assumption that it is only when Black people can come to terms with what they were designed to be that they can participate in the divine design. It then goes without saying that the URCSA needs to realise her position and take seriously the warnings of Wright (2004). She needs to learn to get comfortable in her black skin and insists on a history

8.In a similar way, Maluleke and Nadar (2004) refer to this challenge of the castle. 
that has existed in Africa way longer than the arrival of Western Christianity. A church that is conversant with her own context is one which must realise that black people are not yet liberated and as such it cannot continue to behave as if nothing has happened.

\section{Acknowledgements Competing interests}

The author declares that he has no financial or personal relationship(s) that may have inappropriately influenced him in writing this article.

\section{References}

Biko, S., 1987, I write what I like: A selection of his writings, Heinemann, Portsmouth.

Billingsley, A., 1999, Mighty like a river: The black church and social reform, Oxford University Press, Oxford.

Boesak, A., 1998, 'Black and reformed: Contradiction or challenge?', in D. McKim (ed.), Major themes in the Reformed tradition, pp. 416-425, Wipf and Stock Publishers, Eugene. Church order and stipulations of the Uniting Reformed Church in Southern Africa, 2011, BEM, Pretoria.

Cochrane, J., Martin, S. \& Walters, G., 1999, 'Constructing a language of religion in public life', viewed 24 September 2014, from http://web.uct.ac.za/depts/ricsa/ confer/me99/oth_docs/con_lang.htm\#race

Cone, J., 1984, My people: Black theology and the black church, Orbis books, Maryknoll.

Cone, J., 1992, The spirituals and the blues. Orbis Books, Maryknoll.

Cone, J., 1993, 'Black theology and the black church: Where do we go from here?', in J. Cone \& G. Wilmore (eds.), Black theology: A documentary history, vol. 1, 19661979, pp. 266-278, Orbis Books, Maryknoll.

Conrad, J., 2007, Heart of darkness, Canyon Press, Coyete.

Cruse, H., 1967, The crisis of the Negro intellectual, New York Review Books, New York.

Dangarembga, T., 1998, Nervous conditions, Ayebia Clarke Publishing, Oxfordshire.

Die N.G. Kerk in the O.V.S en die Naturelle Vraagstuk, 1929, Bloemfontein.

Dwane, S., 2004, 'Christianity in Africa: The contribution of the Ethiopian Movement,' in E. Conradie (ed.), African Christian theologies in transition, pp. 75-85, EFSA, Stellenbosch.

Hegel, G.W.F., 1956, The philosophy of history, transl. J. Sibree, Dover Publications Inc., New York.

Hopkins, D.N., 2002, Heart and head: Black theology, past, present and future, Palgrave, New York. http://dx.doi.org/10.1057/9780312299187
Hopkins, D.N. \& Antonio, E.P. (eds.), 2012, The Cambridge companion to Black theology, Cambridge University Press, Cambridge. http://dx.doi.org/10.1017/ theology, Cambridge
CCOL9780521879866

Kritzinger, J.N.J., 1984, 'From broederkring to Belydende Kring: What's in a name?', in S.P. Govender (ed.), Unity and justice: The witness of the Belydende Kring, pp. 5-12, EAATSA, Braamfontein.

Kritzinger, J., 2010, 'Ministerial formation praxis in the Uniting Reformed Church in South Africa: In search of inclusion and authenticity', Missionalia 38(2), 211-234.

Lincoln, E. \& Mamiya, L., 1990, The black church in the African American experience, Duke University Press, Durham. http://dx.doi.org/10.1215/9780822381648

Mafeje, A., 1975, "Religion, class and ideology in South Africa', in M.G. Whisson (ed.), Religion and social change in Southern Africa: Anthropological essays in Honour of Monica Wilson, pp. 165-184, Rex Collings Ltd., Cape Town.

Maluleke, T.S., 1997, 'Truth, national unity and reconciliation in South Africa: Aspects of the emerging theological agenda', Missionalia 25(1), 59-86.

Maluleke, T.S., 2011, 'The elusive public of theology: A response to William Storrar', International Journal of Public Theology 5, 79-89. http://dx.doi.org/10. $1163 / 156973211 \times 543751$

Maluleke, T.S. \& Nadar, S., 2004, 'Alien fraudsters in the white academy: Agency in gendered colour', Journal of Theology for Southern Africa, 120, 5-17.

Mbiti, J., 1993, 'An African views American Black theology', in J. Cone \& G. Wilmore (eds.), Black theology: A documentary history, vol. 1, 1966-1979, pp. 379-384, Obis Books, New York.

Mosala, I.J., 1989, Black hermeneutics and black theology in South Africa, Eerdmans, Grand Rapids.

Motlhabi, M., 2007, African theology/Black theology in South Africa: Looking back, moving on, Unisa Press, Pretoria.

Pletsch, C., 1981, 'The three worlds or the division of social scientific labor ca. 19501975', Comparative Study of Society and History 23(4), 565-590. http://dx.doi. org/10.1017/S0010417500013566

Storrar, W., 2008, 'A kairos moment for public theology', International Journal of Public Theology 1(1), 5-25. http://dx.doi.org/10.1163/156973207X194457

Terreblanche, S., 2005, A history of inequality in South Africa: 1652-2002, University of Kwazulu Natal Press, Pietermaritzburg.

Tshaka, R.S., 2010, Confessional theology?: A critical analysis of the theology of Karl Barth and its significance for the Belhar Confession, Cambridge Scholars Publishing, Newcastle.

Vellem, V.S., 2007, 'The symbol of liberation in South African public life: A Black theological perspective', PhD thesis, University of Pretoria.

Vellem, V.S., 2010, 'Prophetic theology in Black theology, with special reference to the Kairos document', HTS Teologiese Studies/Theological Studies 66(1), Art. \#800, 6 pages.

Walshe, P., 1983, Church versus state in South Africa: The case of the Christian Institute, Orbis Books, Maryknoll.

Wilmore, G., 1984, Black religion and Black radicalism: An interpretation of the religious history of Afro-American people, Orbis Books, Maryknoll.

Woodson, C.G., 2008, The mis-education of the Negro, Classic House Books, New York.

Wright, J.A., 2004, 'Doing black theology in the black church', in L. Thomas (ed.), Living stones in the household of God: The legacy and future of black theology, Fortress Press, Minneapolis. 